\title{
LUT
}

University

\section{Multinational Enterprise and Inclusive Innovation at the Bottom of the Pyramid: A Systematic Literature Review}

Mortazavi Sina, Laine Igor, Quarshie Anne, Väätänen Juha, Gupta Suraksha

This is a Author's accepted manuscript (AAM) version of a publication

published by Palgrave Macmillan, Cham

in International Business and Emerging Economy Firms. Palgrave Studies of Internationalization in Emerging Markets.

DOI: $10.1007 / 978-3-030-24482-8 \_2$

Copyright of the original publication: (c) The Author(s) 2020

Please cite the publication as follows:

Mortazavi S., Laine I., Quarshie A., Väätänen J., Gupta S. (2020) Multinational Enterprise and Inclusive Innovation at the Bottom of the Pyramid: A Systematic Literature Review. In: Marinov M., Marinova S., Larimo J., Leposky T. (eds) International Business and Emerging Economy Firms. Palgrave Studies of Internationalization in Emerging Markets. Palgrave Macmillan, Cham

This is a parallel published version of an original publication. This version can differ from the original published article. 


\title{
Multinational Enterprise and Inclusive Innovation at the
}

\author{
Base of the Pyramid: A Systematic Review
}

Sina Mortazavi, Igor Laine, Anne Quarshie, Juha Väätänen, and Suraksha Gupta

\section{Introduction}

Starting with the two groundbreaking articles by the late C.K. Prahalad co-authored with Stuart Hart (Prahalad and Hart 2002) and Allen Hammond (Prahalad and Hammond 2002) as well as his bestseller book titled The Fortune at the Bottom of the Pyramid: Eradicating Poverty through Profits (Prahalad 2004) attention to the markets forming so-called the bottom or base of the pyramid $(\mathrm{BoP})$ has been growing rapidly within academia, policy and managerial practice (Chataway, Hanlin, and Kaplinsky 2014; Heeks, Foster, and Nugroho 2014). Although policymakers, various supranational institutions, and think tanks have been developing and implementing various solutions to the problem of poverty and disenfranchisement for a number of decades relying mostly on national, international and supranational aid programs and subsidies, their actions are still far from sufficient. In fact, according to Karnani (Karnani 2011), the number of people in poverty has been rather constant for the last 30 years around 2.5 billion people. Looking beyond averages, regional data shows that recent reduction in figures of global poverty is due to huge progress in China, while other territories such as Sub-Saharan Africa and India witnessed increased numbers of people below the poverty line (Chataway, Hanlin, and Kaplinsky 2014). Considering this modest pace of (positive) change, the United Nations (United Nations 2016) Sustainable Development Goal focused on the eradication of extreme poverty for all people everywhere by 2030 seems rather challenging. That is even if increasingly drastic measures and the joining of forces between national, international and local actors from 
governmental, private and non-governmental sectors ( Selsky and Parker 2005; Seitanidi and Lindgreen 2010) would be achieved.

Drawing on Prahalad's visionary and inspirational work, the corporate sector has picked up the challenge with enthusiasm but their initiatives at the BOP achieved various degrees of success as well (Karnani 2007; Simanis and Duke 2014; Angeli and Jaiswal 2015). In some industries, such as telecommunications, fast-moving consumer goods, and healthcare, multinational enterprises (MNEs) have been able to achieve considerable success. On the other hand, even some of the most well-known innovations at the BOP, such as Single Serve Revolution (sachets) and the proliferation of microcredit organizations, raise a substantial amount of scepticism relative to their social value or net contribution to the alleviation of the poverty (Karnani 2011).

Academic attention to the BOP is currently producing an exponentially growing number of research articles on the topic (Kolk, Rivera-Santos, and Rufín 2014; Nahi 2016). Particularly, three special issues in academic journals, one in Journal of Management Studies (George, McGahan, and Prabhu 2012) and two in Innovation and Development (Heeks, Foster, and Nugroho 2014; Santiago 2014), combined with a growing stream of research in various outlets have addressed the topic of inclusive innovation at the BOP, providing a substantial and enlarging knowledge base.

Responding to the calls for international business (IB) scholars to join the discussion on the developmental impact of MNEs within broader discussion around Grand Challenges, such as global poverty, hunger, and inequalities (Ghauri and Buckley 2006; Buckley, Doh, and Benischke 2017), the focus of this study is on the role of multinational enterprise (MNE) in the generation of inclusive innovation as a solution to the problems at the bottom of the pyramid. As 
the IB field still lacks a holistic, systematized and evidence-based understanding how multinational companies can attain mutually beneficial inclusive innovation at the bottom of the pyramid, our study aims to fill this knowledge gap. To address the above-stated research question, we conduct a systematic literature review (Denyer and Tranfield 2009) on the topic, focusing on research published in business and management journals. By addressing this question, we aim to develop an integrative framework that depicts building blocks of inclusive innovation from the perspective of MNE. Our study is based on 51 relevant articles, which were thoroughly evaluated and content analyzed (for methodology, theoretical lenses, industry context and geographic setting) using a carefully developed coding system. Overall, our thorough reading of the BoP literature enables us to identify and classify various mechanisms within MNEs which help to attain inclusive innovation at the BOP, as well as to propose ideas for further research on the topic.

Following the introduction, the remaining four sections of the chapter are the following. First, to set up the stage the background section aims to introduce the concepts and the recent debate on the topic in more detail. The subsequent section describes the methodology of our systematic literature review, including an explanation of article selection procedures, exclusion criteria, the coding system, and analysis. The next section shows and discusses the results of our literature review, while the last section concludes the discussion with implications for academia, policy-makers, and practitioners.

\section{Conceptual background}

For the last decade, emerging markets have been the major engine for growth to many MNEs thus allowing them to balance any declines and losses in stagnant and hypercompetitive developed economies (London and Hart 2004). Liberated economic policies of some of the 
emerging markets have attracted substantial foreign direct investments and helped to increase the livelihood and population of the middle class in most of these countries (Meyer 2004). At the same time, the continuous debate around globalization is not coming to a conclusion, while antiglobalists movement claims that benefits of globalization are only for rich, while poor remain poor. Although hard data suggests that the gap has been decreasing on average, a closer look indicates that positive effects of global integration coupled with foreign aid are not universal ( Stiglitz 2002; Moyo 2009) while the livelihood of the poorest layers of people in particular countries seems largely unattained ( Wade 2004; Chataway, Hanlin, and Kaplinsky 2014). An explanation of this stem from the exclusion of the poorest people from all the major economic processes, thus blocking any positive spillover effects and galvanizing further unrest and crises.

The BOP broadly refers to the world's four billion consumers who live on $\$ 5$ or less per day (Prahalad and Hart 2002; Rangan, Chu, and Petkoski 2011). The BOP market comprises 70\% of the world's population located in least-developed countries and rural areas of developing and emerging economies (Webb et al. 2010). In addition to small income, being poor is expensive in terms of the cost of access to the most basic needs such as drinking water, food, credit, mobile connection, and internet. At the BOP, the prices might include a premium or so-called poverty penalty of up to 50 times of the normal price and even more (Prahalad and Hammond 2002; Mendoza 2011). Although there are dozens of definitions for the BOP and various income levels suggested to define it (Kolk, Rivera-Santos, and Rufín 2014; Nahi 2016), there is a consensus that reduction of poverty at the base of the pyramid remains the Grand Challenge to struggle with. We believe that inclusion of the base of the pyramid into economic processes can not only improve the livelihood of people at the BOP but can also generate sustainable innovations and become the next engine for global growth. Considering both inclusion and innovation as 
complementary prerequisites for cumulative economic growth, inclusive innovation, defined as "means by which new goods and services are developed for and by marginal groups" (Heeks et al. 2013), seems to be a feasible instrument at hand.

Provided that innovative capacity is largely stocked within large multinational corporations (Narula and Zanfei 2005; Nieto and Rodríguez 2011; Jaruzelski, Schwartz, and Staack 2015; European Commission 2017), we allege that it is exactly at their hand as well as interest to address the problem. While not being too naïve to rely solely on the intrinsic will to help the poorest and corporate social responsibility of multinational companies, inclusive innovation should be motivated by opportunities to form a solid basis for successful business, thus being mutually beneficial. At the same time, innovations originated in (or for) such an inputsensitive markets of the BOP are expected to have further implications for global technological progress in relation to the sustainability of traditional products and solutions, thus benefiting to society at large as well (Prahalad and Mashelkar 2010). While the number of business R\&D centres in some of the emerging economies such as China and India rapidly increases, it transforms these countries into innovation hubs for MNEs from various countries (UNESCO 2015). Moreover, we can see a growing trend for rising $R \& D$ expenditures by emerging markets multinationals, thus building innovation capacity residing in markets where a substantial number of people leave below the poverty line (Dellermann 2017). Having this in mind, the purpose of the current study is to systematize the reported knowledge on how multinational enterprises can attain an inclusive innovation at the base of the pyramid without compromising on their own profits.

\section{Methodology}


In this study, we use a systematic literature review methodology (Denyer and Tranfield 2009). Literature reviews have become a commonly used methodology in business and management research, including the IB field (Doh et al. 2010; Laufs and Schwens 2014; Martineau and Pastoriza 2016; Pisani et al. 2017), because they allow scholars to effectively synthesize findings of large numbers of previous studies. Structured or systematic reviews are a particularly rigorous way of analyzing previous literature (Denyer and Tranfield 2009; Carter and Easton 2011).

As we sought to conduct a robust study with reliable and valid results, all steps of our multi-stage research process (see Figure 1) were guided by a research protocol, which explicitly described the procedures for article search, inclusion, coding and analysis. In the following subsections, we outline these procedures in detail.

Insert Figure 1 about here

\section{Article Search}

As the first stage in the research process, we decided on the sampling criteria for potentially relevant articles. To improve the transparency and replicability of the study, we used an electronic keyword search as our main method for finding articles. As we wanted to focus on high-quality scholarly journal articles (also Lorentz, Kumar, \& Srai, 2017), we decided to search for potentially relevant articles from the Scopus database, which includes journals carefully and continuously evaluated for their impact and quality status. Because we were especially keen on finding articles that relate to business and management studies, we only searched for articles from the 'Business, Management and Accounting' subject area. Based on previous articles focusing on the topic of inclusive innovation (George, McGahan, and Prabhu 2012; Heeks, Foster, and 
Nugroho 2014), as well as prior reviews on other concepts focal to our study (Kolk, RiveraSantos, and Rufín 2014; Nahi 2016), we developed a list of keywords to be used in the article search. Several iterations of the electronic search were performed by two of the authors, and finally, combinations of the following keywords were used to search for articles: "innovation", "inclusive", "frugal”, "growth", and "pyramid". The keyword "pyramid" was utilized to bring articles referring to the concepts of the bottom of the pyramid and the base of the pyramid. The keywords were searched from the article titles, keywords, and abstracts. Articles that contained these keywords were included in our database for potentially relevant articles for further evaluation, resulting in 262 such articles in total.

\section{Article Inclusion Decisions}

As a result of the article search, we had 262 articles in our research database, and these articles were next evaluated by two authors to determine their relevancy for our study. All of these articles were research articles from peer-reviewed academic journals, because as in similar types of literature reviews (López-Duarte, Vidal-Suárez, and González-Díaz 2016; Quarshie, Salmi, and Leuschner 2016; Pisani et al. 2017), we had left out introductions to special issues, editorials, and book reviews. The inclusion of each article was thoroughly discussed by two members of the research team, who had both examined the articles independently and recorded a recommendation for exclusion or inclusion based on previously decided upon criteria. Each article needed to 1) meet criteria derived from the definition of inclusive innovation, and 2) be contextualized at the BOP markets. We first evaluated the articles for two specific criteria related to the definition of inclusive innovation. First, each article needed to deal with some type innovation (e.g. product, business model, or process). Second, the innovation needed to involve otherwise excluded or disenfranchised groups of people or communities (e.g. the elderly, 
handicapped, indigenous people, or other groups at the BoP). According to Heeks, Foster, and Nugroho (Heeks, Foster, and Nugroho 2014), the inclusion of these otherwise marginalized people can occur into different aspects of innovation, thus there are different levels of inclusive innovations and our review consider inclusion at these various levels. Based on these initial assessments, 136 articles were discarded. We then evaluated the remaining 126 articles for whether they explicitly dealt with MNEs, and excluded articles that did not have implications for MNE. During the second step, additional 75 articles were eliminated, and the final sample of the study was hence 51 articles. The distribution of articles per journals in our sample is presented in Table 1.

Insert Table 1 about here

\section{Article Coding System}

To improve our study's rigour and replicability, we carefully developed an article classification system, which was adapted from prior systematic review studies. The system for coding the articles for research methodologies, industry setting, and the geographic context of the study is based on the content classification system used in Quarshie et al. (2016) study (also Carter \& Easton, 2011). Because not all of their categories were relevant to our study, we left out several categories (e.g. sustainability dimensions) but added a new category focused on the headquarter location of MNEs. Our coding system appears in Table 2, which presents the results of our analysis.

Insert Table 2 about here 
Additional details about our coding labels are shown in Table 3.

\section{Insert Table 3 about here}

\section{Article Analysis and Synthesis}

Two members of the research team read and coded each of the 51 articles included in the sample using the developed coding system. Each article was assigned one main code per category (e.g. one research methodology code). The coding were then discussed by the two authors performing the coding, and final decisions on the codes were made. Further, the main themes and findings of the articles were examined and synthesized (Kolk 2016; Pisani et al. 2017) and will be discussed in detail in the next section.

\section{Results}

As previously described, our final sample consisted of 51 scholarly articles that dealt with inclusive innovation and had a clear MNE focus. The articles had appeared in 36 journals from a variety of fields, including innovation research, marketing, corporate social responsibility, international business (IB), and organizational and management studies, among others. From our entire sample, 31 articles had appeared in journals belonging to the ABS list. Three studies appeared in journals from the 'International Business and Area Studies' field: the Asia Pacific Journal of Management, Journal of International Management, and International Journal of Emerging Markets. Only eight of the 36 journals had published more than one article included in our sample (see Table 1), which suggests that the research field is relatively fragmented. However, the time-distribution of the articles (Figure 2) reveals that research interest on the topic 
appears is growing rapidly. All articles in our sample appeared during the past fifteen years, but only three of the included articles were published in 2003-2009, while the remaining 48 articles (94 percent) appeared during this decade (Figure 2).

Insert Figure 2 about here

\section{Results of Content Analysis}

In content analyzing the articles, we had coded each article for the applied research methodologies, industry settings, and the headquarters location of the MNEs as well as the context of the study (Table 2). In the following subsections, we present the results of this analysis, before synthesizing the literature.

Research methods. Our examination of the utilized research methodologies showed that scholars have heavily favored case studies (Tiwari and Herstatt 2012; Silvestre and Neto 2014), conceptual approaches (Chakravarthy and Coughlan 2011; Pels and Sheth 2017), as well as literature reviews (Gupta 2017) in this field. In contrast, there were no survey studies in our database, and additional methodologies, such as ethnographies (Pansera and Owen 2015; Halme et al. 2016), were used to a limited extent.

Industry settings. In nearly half of the articles in our sample (23 articles), research was conducted or focused on a single-industry setting. The most common sectors in this category were services (Ray and Ray 2010; Foster and Heeks 2013) and consumer goods (Ojha 2014). The remaining 28 articles were divided almost equally between studies that had a multiple industry setting (15 articles) and those where the industry was not specified (13 articles). Multiple industry articles were often case studies involving sectors such as services, consumer goods, and 
food and beverages ( Sánchez and Ricart 2010; Gebauer et al. 2017). The industry was commonly coded as 'Not specified' in conceptual papers (Williams, Omar, and Ensor 2011), in particular.

Geographic context of MNEs. As for the geographic context (i.e. headquarter location) of the MNEs, single-continent studies most often focused on activities by European, North American or Asian companies, while only a few articles were on Latin American (Gebauer and Reynoso 2013; Hall, Matos, and Martin 2014; Gutiérrez and Vernis 2016;) or African (Rosca, Arnold, and Bendul 2017) MNEs. The remaining articles included multiple continent studies, as well as some articles where the context of the MNE was not specified or applicable.

Geographic context of the study. Interestingly, our examination of the geographic context of the study itself revealed that researchers in nearly half of the articles conducted their studies or focused on a single continent context, the most popular choices being Asia (Van den waeyenberg and Hens 2008; Prabhu and Jain 2015;) and Africa (Hemphill 2010; Foster and Heeks 2013). The multiple-continent articles, on the other hand, involved a broad variety and mix of continents, which were investigated using empirical as well as literature-based methods. The articles where the study context was coded as 'Not specified' were most commonly conceptual papers.

\section{Literature Synthesis}

Our synthesis of the reviewed literature allowed to classify the extant body of knowledge into seven topics or thematic areas described in the remainder of this section. Based on the synthesis, the integrative framework illustrated below (Figure 2) represents the building blocks of inclusive innovation at the BOP from the perspective of a multinational enterprise. 
Insert Figure 2 about here

Topic 1: Innovation. Most of the studies in our sample fall into this category under one of the three subcategories, namely 1) types of innovations, 2) factors enabling or constraining innovation, and 3) innovation processes.

Thirteen various types of innovation generated at and for the BOP markets and their implications for MNEs are represented in the table below (Table 4).

Insert Table 4 about here

Research on different factors (drivers and constraints) to innovation represent a substantial group of articles on the topic of innovation. In their case study, Lim et al. (2013) investigated how innovation capability building through leverage of external resources can help a resource-deficient firm to foster innovation at the BOP. (National) System of Innovations is another popular stream of research in this subcategory, while efficient development of innovations in the BOP markets is largely affected by strengths and weaknesses of national innovation systems (Hemphill 2010; Chakravarthy and Coughlan 2011; Chew, Watanabe, and Tou 2011; Reid and Ramani 2012; Ojha 2014; Pansera and Owen 2015; Andersen and Andersen 2017). Harmon and Kale (2015), for instance, analyze how governing bodies of the BOP markets and regulatory environments can cause barriers to innovation for MNEs.

The last subcategory of research on the topic of innovation, considers innovation processes, including research on diffusion of innovation (Ndyabawe and Kisaalita 2014; Rabino 2015; Hossain, Simula, and Halme 2016) and innovation cycle (Kaplinsky 2011). Process-based 
research implies rather distinctive methodological approaches and while ethnographic methods are known to be useful to provide deep knowledge of life practices and social needs at the BOP, Halme et al. (2016) showcased how multi-sited rapid ethnography can be integrated into innovation processes of MNEs to generate inclusive innovation at the BOP.

Topic 2: CSR and sustainability. Several articles investigation capability building for the BOP markets through a more CSR oriented perspective. Several articles claimed that frugal innovation, Prahalad's principle of innovation and innovation competencies can give MNEs a ground for reducing poverty and creating jobs (Blake 2006; Nari Kahle et al. 2013; Oodith and Parumasur 2014). Some articles argued that partnership and ties between MNEs and local organizations are important elements when building local capabilities for the BOP markets (Gutiérrez and Vernis 2016; Gupta 2017). However, Van den waeyenber and Hens (2012) views social capability building as a result of MNEs with stronger customer-centric vision and hightech product development.

Topic 3: Business model. Business model perspective is extensively used among the sampled articles, largely advocating for substantial change in business models when MNEs pursue opportunities at the BOP (Gebauer, Haldimann, and Saul 2017). Part of the articles (Angeli and Jaiswal 2016; Gebauer, Haldimann, and Saul 2017) showed that business models could be a crucial tool for MNEs to foster innovation and scalability through value proposition and value creation. Likewise, some studies documented that, larger MNEs can achieve bricolage and tackle resource barriers in BOP markets through business models integrations shaping inclusive business (Halme, Lindeman, and Linna 2012) while other scholars claimed that business model of MNEs can help them overcome legitimacy challenges in BOP markets (Arora and Kazmi 2012). Some articles studied the benefit of a more focused business models 
perspective by MNEs leading to a more effective social innovation in service and telecom sectors (Reynoso et al. 2015). Similar studies examined the importance of business model planning for achieving frugal and reverse innovation by MNEs (Rosca, Arnold, and Bendul 2017) while others compared isolated and interactive business model for MNEs for overcoming the ecosystem barriers of BOP markets (Sánchez and Ricart 2010).

Topic 4: Strategy. Several articles in the selected sample used strategic management notions for their analyses. Foster and Heeks (2013) assert the importance of organizational strategy enabling scaled ICT innovation in the BOP markets. Other studies investigated various strategies for successful operations at the BOP markets, including among others branding (Gupta 2017), blue ocean (Williams, Omar, and Ensor 2011) and low-cost (Oodith and Parumasur 2014) strategies. Some scholars stressed more on some elements that need to be included in the process of rendering strategies by MNEs. For instance, some studies suggested that when developing strategies MNEs need to pay attention to various contingent factors such as possible spillover effect (Hill and Mudambi 2010) and political ties (Malik 2017). Another direction of research advocated for knowledge and learning based strategies useful for enhancement of MNEs' innovation capabilities (Conceição, Heitor, and Veloso 2003; Ray and Ray 2010; Rabino 2015; Rao 2017).

Topic 5: Marketing. Several articles in our data set did focus on marketing dimensions. Some studies suggest that companies can build more capabilities for the BOP markets through a more robust market research (Van den waeyenberg and Hens 2012), while some argued that marketing tools such as branding image by MNEs play a role in poverty reduction (Gupta 2017). Other studies have focused on the service-dominant logic for creating service innovation (Gebauer and Reynoso 2013), market adaptation notion for creating inclusive ecosystems (Pels 
and Sheth 2017), the lead market model for frugal innovation (Tiwari and Herstatt 2012).

Kotler's transactional marketing approach (4Ps) has been also applied for the BOP market (Van den waeyenberg and Hens 2008), although others (Oodith and Parumasur 2014) suggested that MNEs should rather embrace the 4As (Availability, Affordability, Awareness, Acceptability) as a better-fit alternative.

Topic 6: Entrepreneurship and SMEs. Several studies examine innovation for the BOP markets through the prism of entrepreneurship, highlighting specific entrepreneurial capabilities of local people at the BOP (Prabhu and Jain 2015) as well as the roles of local entrepreneurs in the BOP ecosystems (Ray and Ray 2010). Another stream of studies claims that the best way to succeed in the BOP market is for MNEs to use local entrepreneurs as intermediaries (Hill and Mudambi 2010; Pervez, Maritz, and De Waal 2013) resulting in stronger innovation abilities. Dellermann (2017) showcased how reverse innovation co-developed with collaborators located in emerging markets represent a viable strategy for a western SME operating in the healthcare industry. As opposed to hierarchical operational modes implying FDI, network-based approach allowed a company to develop and launch the product simultaneously to many markets as opposed to (one) market(s) of physical presence. Although this case does not consider an MNE as such, the showcased strategic option represent an alternative similarly available for MNEs highlighting some of the advantages of non-FDI operation modes at the BOP. Halme, Lindeman and Linna (2012) examined how a particular entrepreneurial activity, namely intrapreneurial bricolage, can help MNE to overcome certain organizational rigidities on the way to pro-poor business innovation.

Topic 7: Ecosystem perspective and network approach. In this topic small portion of the studies, highlight the role of the ecosystem in fostering inclusive innovation at the BOP (Sánchez 
and Ricart 2010; Rong, Liu, and Shi 2011; Pels and Sheth 2017). In this regard, all these articles suggested that inclusive business (i.e. operating in the low-income markets) can be feasible through taking into account ecosystem perspective into the business model of the company. Pels and Sheth (2017) and Rong et al. (2011) developed similar conceptual models aiming to form a business model of inclusive ecosystems when the market is seen as a set of systems and linkages between different organizations and people. Pels and Sheth (2017) developed a two-by-two matrix business model containing opportunities and constraints of serving the low-income consumers, where inclusive ecosystem and radical innovation are elements that generate opportunities while mission focus and market adaptation are seen as market constraints for MNEs. Mekina (2017) explicated the role of financial services in the BOP ecosystem in Africa to provide access to credit for the needy people of the society. The findings of the study suggest that partnerships between government and companies can foster financial inclusion (Resulting in more credit and loans for the people) for the low-income societies in Africa so that people can afford mobile phones. Hemphill (2010) confirmed that stronger links between government and MNEs would result in more robust financial services for the poor societies. In addition, the same source argues that providing subsidies and incentives by the government for MNEs will facilitate innovation that alleviates poverty.

\section{Conclusions, limitations and future research}

In this literature review, we systematically assessed and synthesized academic literature focusing on inclusive innovation by MNEs at the base of the pyramid (BoP). Our study covered 51 research articles published in 36 high-quality business and management journals, which were gathered and content analyzed in a structured research process. Our review suggests that inclusive innovation can be generated by the MNEs utilizing various approaches suggested by 
seven streams of literature identified in our review (Innovation, entrepreneurship, marketing, strategy, CSR, business model, ecosystems) as shown in Figure 3. These seven classification can advance the literature in IB as it provides a mechanism for scholars as well as practitioners on the role of ININ. Likewise, this mechanism sheds light on the different tools that are essential for fostering ININ at the BOP.

Our analysis revealed that qualitative or literature-based methodologies were used in the vast majority of studies, while survey research was neglected and additional methodologies were used to a limited extent. Moreover, we found that prior research has focused heavily on singleindustry settings, especially in the services and consumer goods sectors. As for geographic context areas, our data suggests that researchers commonly focus on activities by Western or Asian MNEs in Asia in this research field. Based on a synthesis of the literature, we developed an initial integrative framework, which categorizes the main elements of inclusive innovation by MNEs.

As for limitations, our study had a restricted sample and was deliberately focused on the role of inclusive innovation generated or co-created by multinational corporations at the BOP. While our structured review is based on a thorough literature search and deals extensively with this one force in the battle against poverty and economic exclusion at the BoP, the limited scope of our review provides opportunities for scholars to broaden our understanding of the phenomenon. In further literature review studies, scholars could consider retrieving and including additional articles that focus on similar markets (e.g. in emerging and developing country contexts) but do not refer explicitly to the BoP (e.g. Mair et al., 2012). Moreover, while our study has a clear MNE focus, inclusive innovation can be co-created through various contingent and complementary actions and measures undertaken by national, international and supranational 
institutions, NGOs and civil society groups - in addition to the private sector. Our review suggests that multinational and other corporations have the substantial collaborative capacity to work with other actors, but their success at the BoP is largely dependent on their capability to engage with additional actors.

Future research, including literature reviews as well as empirical studies, could explore and debunk the various parts of the solutions for eradicating poverty, economic exclusion and other problems at the BoP. For example, researchers could develop more focused research questions within the thematic areas identified in our research. Additionally, work on the other thematic areas and other subcategories of identified themes not covered by the reviewed articles, such as industrial marketing, international human resource management. Surprisingly, as our review revealed research had not addressed the topic appeared in top journals in the International Business domain, although it is argued that international business scholars have vast potential in this area. Notably, studies that focused on multiple industrial contexts can be explored more by IB scholars are particularly well-positioned to investigate such issues because of their understanding of contextual conditions in emerging and developing markets. Conceptually, the concept of inclusive innovation lacks conceptual clarity and proper definition, this work in this direction would open up further opportunities for scale development facilitating survey based studies. 


\section{References}

Andersen, A. D., \& Andersen, P. D. (2017). Foresighting for inclusive development. Technological Forecasting and Social Change, 119, 227-236.

Angeli, F., \& Jaiswal, A. K. (2015). Competitive Dynamics between MNCs and Domestic Companies at the Base of the Pyramid: An Institutional Perspective. Long Range Planning, 48(3), 182-199.

Angeli, F., \& Jaiswal, A. K. (2016). Business Model Innovation for Inclusive Health Care Delivery at the Bottom of the Pyramid. Organization \& Environment, 29(4), 486-507.

Arora, B., \& Kazmi, S. B. A. (2012). Performing Citizenship. Business \& Society, 51(3), 450477.

Blake, J. (2006). From protection to innovation: BT's journey in corporate social responsibility. Global Business and Organizational Excellence, 26(1), 7-17.

Buckley, P. J., Doh, J. P., \& Benischke, M. H. (2017). Towards a renaissance in international business research? Big questions, grand challenges, and the future of IB scholarship. Journal of International Business Studies, 48(9), 1045-1064.

Carter, C. R., \& Easton, P. L. (2011). Sustainable supply chain management: evolution and future directions. International Journal of Physical Distribution \& Logistics Management, 41, 4662.

Chakravarthy, B., \& Coughlan, S. (2011). Emerging market strategy: innovating both products and delivery systems. Strategy \& Leadership, 40(1), 27-32.

Chataway, J., Hanlin, R., \& Kaplinsky, R. (2014). Inclusive innovation: an architecture for policy development. Innovation and Development, 4(1), 33-54.

Chew, M. Y. C., Watanabe, C., \& Tou, Y. (2011). The challenges in Singapore NEWater development: Co-evolutionary development for innovation and industry evolution. Technology in Society, 33(3-4), 200-211.

Conceição, P., Heitor, M. V., \& Veloso, F. (2003). Infrastructures, incentives, and institutions: 
Fostering distributed knowledge bases for the learning society. Technological Forecasting and Social Change, 70(7), 583-617.

Dellermann, D. (2017). Going East: a framework for reverse innovation in SMEs. Journal of Business Strategy, 38(3), 30-39.

Denyer, D., \& Tranfield, D. (2009). Producing a Systematic Review. In D. Buchanan \& A. Bryman (Eds.), The SAGE Handbook of Organizational Research Methods (pp. 671-689). London, UK: SAGE Publications Ltd.

Doh, J., Husted, B. W., Matten, D., \& Santoro, M. (2010). Ahoy There! Toward Greater Congruence and Synergy Between International Business and Business Ethics Theory and Research. Business Ethics Quarterly, 20(3), 481-502.

European Commission. (2017). The 2017 EU Industrial R\&D Investment Scoreboard. Luxembourg.

Foster, C., \& Heeks, R. (2013). Innovation and scaling of ICT for the bottom-of-the-pyramid. Journal of Information Technology, 28(4), 296-315.

Gebauer, H., Haldimann, M., \& Saul, C. J. (2017). Business model innovations for overcoming barriers in the base-of-the-pyramid market. Industry and Innovation, 24(5), 543-568.

Gebauer, H., \& Reynoso, J. (2013). An agenda for service research at the base of the pyramid. Journal of Service Management, 24(5), 482-502.

Gebauer, H., Saul, C., Halidmann, M., \& Kramer, S. (2017). When one business model is not enough for a social business. Strategic Direction, 33(1), 10-12.

George, G., McGahan, A. M., \& Prabhu, J. (2012). Innovation for Inclusive Growth: Towards a Theoretical Framework and a Research Agenda. Journal of Management Studies, 49(4), $661-683$.

Ghauri, P. N., \& Buckley, P. J. (2006). Globalization, multinational enterprises andworld poverty. In S. C. Jain \& S. Vachani (Eds.), Multinational Corporations and Global Poverty Reduction (pp. 204-232). Cheltenham, UK: Edward Elgar Publishing.

Gupta, S. (2017). Returns on social development initiatives of MNEs: issues and perspectives. 
Qualitative Market Research: An International Journal, 20(2), 126-146.

Gutiérrez, R., \& Vernis, A. (2016). Innovations to Serve Low-Income Citizens: When Corporations Leave Their Comfort Zones. Long Range Planning, 49(3), 283-297.

Hall, J., Matos, S. V, \& Martin, M. J. C. (2014). Innovation pathways at the Base of the Pyramid: Establishing technological legitimacy through social attributes. Technovation, 34(5-6), 284294.

Halme, M., Kourula, A., Lindeman, S., Kallio, G., Lima-Toivanen, M., \& Korsunova, A. (2016). Sustainability Innovation at the Base of the Pyramid through Multi-Sited Rapid Ethnography. Corporate Social Responsibility and Environmental Management, 23(2), 113128.

Halme, M., Lindeman, S., \& Linna, P. (2012). Innovation for Inclusive Business: Intrapreneurial Bricolage in Multinational Corporations. Journal of Management Studies, 49(4), 743-784.

Harmon, S. H. E., \& Kale, D. (2015). Regulating in developing countries: Multiple roles for medical research and products regulation in Argentina and India. Technology in Society, 43, $10-22$.

Heeks, R., Amalia, M., Kintu, R., \& Shah, N. (2013). Inclusive Innovation: Definition, Conceptualisation and Future Research Priorities (No. 53). Development Informatics. Manchester, UK.

Heeks, R., Foster, C., \& Nugroho, Y. (2014). New models of inclusive innovation for development. Innovation and Development, 4(2), 175-185.

Hemphill, T. (2010). The "creative capitalism” corporate governance model. International Journal of Law and Management, 52(2), 110-123.

Hill, T. L., \& Mudambi, R. (2010). Far from Silicon Valley. Journal of International Management, 16(4), 321-327.

Hossain, M., Simula, H., \& Halme, M. (2016). Can frugal go global? Diffusion patterns of frugal innovations. Technology in Society, 46, 132-139.

Jaruzelski, B., Schwartz, K., \& Staack, V. (2015). The 2015 Global Innovation 1000 - 
Innovation's new world order. Strategy\&, (October), 1-20.

Kaplinsky, R. (2011). Schumacher meets Schumpeter: Appropriate technology below the radar. Research Policy, 40(2), 193-203.

Karnani, A. (2007). The Mirage of Marketing to the Bottom of the Pyramid: How the Private Sector Can Help Alleviate Poverty. California Management Review, 49(4), 90-111.

Karnani, A. (2011). Fighting Poverty Together. Fighting Poverty Together: Rethinking Strategies for Business, Governments, and Civil Society to Reduce Poverty. New York: Palgrave Macmillan US.

Kolk, A. (2016). The social responsibility of international business: From ethics and the environment to CSR and sustainable development. Journal of World Business, 51(1), 23-34.

Kolk, A., Rivera-Santos, M., \& Rufín, C. (2014). Reviewing a Decade of Research on the "Base/Bottom of the Pyramid" (BOP) Concept. Business \& Society, 53(3), 338-377.

Laufs, K., \& Schwens, C. (2014). Foreign market entry mode choice of small and medium-sized enterprises: A systematic review and future research agenda. International Business Review, 23(6), 1109-1126.

Lim, C., Han, S., \& Ito, H. (2013). Capability building through innovation for unserved lower end mega markets. Technovation, 33(12), 391-404.

London, T., \& Hart, S. L. (2004). Reinventing strategies for emerging markets: beyond the transnational model. Journal of International Business Studies, 35(5), 350-370.

López-Duarte, C., Vidal-Suárez, M. M., \& González-Díaz, B. (2016). International Business and National Culture: A Literature Review and Research Agenda. International Journal of Management Reviews, 18(4), 397-416.

Lorentz, H., Kumar, M., \& Srai, J. S. (2018). Managing distance in international purchasing and supply: a systematic review of literature from the resource-based view perspective. International Business Review, 27(2), 339-354.

Mair, J., Marti, I., \& Ventresca, M. J. (2012). Building Inclusive Markets in Rural Bangladesh: How Intermediaries Work Institutional Voids. Academy of Management Journal, 55(4): 
819-850.

Malik, O. R. (2017). When Davids start becoming Goliaths: unique capabilities of emergingmarket multinational enterprises and how they foster growth in developed markets? International Journal of Technology Management, 74(1/2/3/4), 45.

Martineau, C., \& Pastoriza, D. (2016). International involvement of established SMEs: A systematic review of antecedents, outcomes and moderators. International Business Review, $25(2), 458-470$.

Mendoza, R. U. (2011). Why do the poor pay more? Exploring the poverty penalty concept. Journal of International Development, 23(1), 1-28.

Meyer, K. E. (2004). Perspectives on multinational enterprises in emerging economies. Journal of International Business Studies, 35(4), 259-276.

Moyo, D. (2009). Dead Aid: Why aid is not working and how there is a better way for Africa. New York, US: Farrar, Straus and Giroux.

Nahi, T. (2016). Cocreation at the Base of the Pyramid: Reviewing and Organizing the Diverse Conceptualizations. Organization and Environment, 29(4), 416-437.

Nari Kahle, H., Dubiel, A., Ernst, H., \& Prabhu, J. (2013). The democratizing effects of frugal innovation. Journal of Indian Business Research, 5(4), 220-234.

Narula, R., \& Zanfei, A. (2005). Globalization of Innovation: The Role of Multinational Enterprises. In J. Fagerberg, D. Mowery, \& R. Nelson (Eds.), The Oxford handbook of innovation (pp. 318-345). Oxford, UK: Oxford University Press.

Ndyabawe, K., \& Kisaalita, W. S. (2014). Diffusion of an evaporative cooler innovation among smallholder dairy farmers of Western Uganda. Technology in Society, 38, 1-10.

Nieto, M. J., \& Rodríguez, A. (2011). Offshoring of RD: Looking abroad to improve innovation performance. Journal of International Business Studies, 42(3), 345-361.

Ojha, A. K. (2014). MNCs in India: Focus on frugal innovation. Journal of Indian Business Research, 6(1), 4-28.

Oodith, P. D., \& Parumasur, S. B. (2014). Being on top of your game at the bottom of the 
Pyramid. Corporate Ownership and Control, 11(3 C), 253-272.

Pansera, M., \& Owen, R. (2015). Framing resource-constrained innovation at the 'bottom of the pyramid': Insights from an ethnographic case study in rural Bangladesh. Technological Forecasting and Social Change, 92, 300-311.

Pels, J., \& Sheth, J. N. (2017). Business models to serve low-income consumers in emerging markets. Marketing Theory, 17(3), 373-391.

Pervez, T., Maritz, A., \& De Waal, A. (2013). Innovation and social entrepreneurship at the bottom of the pyramid - A conceptual framework. South African Journal of Economic and Management Sciences, 16(5), 54.

Pisani, N., Kourula, A., Kolk, A., \& Meijer, R. (2017). How global is international CSR research? Insights and recommendations from a systematic review. Journal of World Business, 52(5), 591-614.

Prabhu, J., \& Jain, S. (2015). Innovation and entrepreneurship in India: Understanding jugaad. Asia Pacific Journal of Management, 32(4), 843-868.

Prahalad, C. K. (2004). The Fortune at the Bottom of the Pyramid: Eradicating Poverty through Profits. Upper Saddle River, NJ: Wharton School Publishing.

Prahalad, C. K., \& Hammond, A. (2002). Serving the world's poor, profitably. Harvard Business Review, (September), 48-57.

Prahalad, C. K., \& Hart, S. L. (2002). The Fortune at the Bottom of the Pyramid. Strategy+Business Magazine, (26), 273.

Prahalad, C. K., \& Mashelkar, R. A. (2010). Innovation's Holy Grail. Harvard Business Review, (July-August), 1-11.

Quarshie, A. M., Salmi, A., \& Leuschner, R. (2016). Sustainability and corporate social responsibility in supply chains: The state of research in supply chain management and business ethics journals. Journal of Purchasing and Supply Management, 22(2), 82-97.

Rabino, S. (2015). The bottom of the pyramid: an integrative approach. International Journal of Emerging Markets, 10(1), 2-15. 
Rangan, K., Chu, M., \& Petkoski, D. (2011). Segmenting the Base of the Pyramid. Harvard Business Review, 89(June), 113-117.

Rao, B. C. (2017). Advances in science and technology through frugality. IEEE Engineering Management Review, 45(1), 32-38.

Ray, P. K., \& Ray, S. (2010). Resource-Constrained Innovation for Emerging Economies: The Case of the Indian Telecommunications Industry. IEEE Transactions on Engineering Management, 57(1), 144-156.

Reid, S. E., \& Ramani, S. V. (2012). The harnessing of biotechnology in India: Which roads to travel? Technological Forecasting and Social Change, 79(4), 648-664.

Reynoso, J., Kandampully, J., Fan, X., \& Paulose, H. (2015). Learning from socially driven service innovation in emerging economies. Journal of Service Management, 26(1), 156-176.

Rong, K., Liu, Z., \& Shi, Y. (2011). Reshaping the business ecosystem in China: case studies and implications. Journal of Science and Technology Policy in China, 2(2), 171-192.

Rosca, E., Arnold, M., \& Bendul, J. C. (2017). Business models for sustainable innovation - an empirical analysis of frugal products and services. Journal of Cleaner Production, 162, S133-S145.

Sánchez, P., \& Ricart, J. E. (2010). Business model innovation and sources of value creation in low-income markets. European Management Review, 7(3), 138-154.

Santiago, F. (2014). Innovation for inclusive development. Innovation and Development, 4(1), 14.

Seitanidi, M. M., \& Lindgreen, A. (2010). Editorial: Cross-Sector Social Interactions. Journal of Business Ethics, 94(S1), 1-7.

Selsky, J. W., \& Parker, B. (2005). Cross-Sector Partnerships to Address Social Issues: Challenges to Theory and Practice. Journal of Management, 31(6), 849-873.

Silvestre, B. S., \& Neto, R. E. S. (2014). Capability accumulation, innovation, and technology diffusion: Lessons from a Base of the Pyramid cluster. Technovation, 34(5-6), 270-283.

Simanis, E., \& Duke, D. (2014). Profits at the bottom of the pyramid. Harvard Business Review, 
92(10), 88-93.

Stiglitz, J. E. (2002). Employment, social justice and societal well-being. International Labour Review, 141(1-2), 9-29.

Tiwari, R., \& Herstatt, C. (2012). Assessing India's lead market potential for cost-effective innovations. Journal of Indian Business Research, 4(2), 97-115.

UNESCO. (2015). UNESCO Science Report: Towards 2030. Paris, France: UNESCO

Publishing. Retrieved from

http://unesdoc.unesco.org/images/0023/002354/235406e.pdf\%5Cnhttp://unesdoc.unesco.org /images/0023/002354/235407e.pdf

United Nations. (2016). The Sustainable Development Goals Report 2016. United Nations (Vol. 2016). United Nations.

Van den waeyenberg, S., \& Hens, L. (2008). Crossing the bridge to poverty, with low-cost cars. Journal of Consumer Marketing, 25(7), 439-445.

Van den waeyenberg, S., \& Hens, L. (2012). Overcoming institutional distance: Expansion to base-of-the-pyramid markets. Journal of Business Research, 65(12), 1692-1699.

Wade, R. (2004). Is Globalization Reducing Poverty and Inequality? World Development, 32(4), $567-589$.

Webb, J. W., Kistruck, G. M., Ireland, R. D., \& Ketchen, D. J. J. (2010). The Entrepreneurship Process in Base of the Pyramid Markets: The Case of Multinational Enterprise/Nongovernment Organization Alliances. Entrepreneurship Theory and Practice, $34(3), 555-581$.

Williams, R. L., Omar, M., \& Ensor, J. (2011). Sourcing or selling: the Value Flame at the Base of the Pyramid. Marketing Intelligence \& Planning, 29(3), 233-246. 


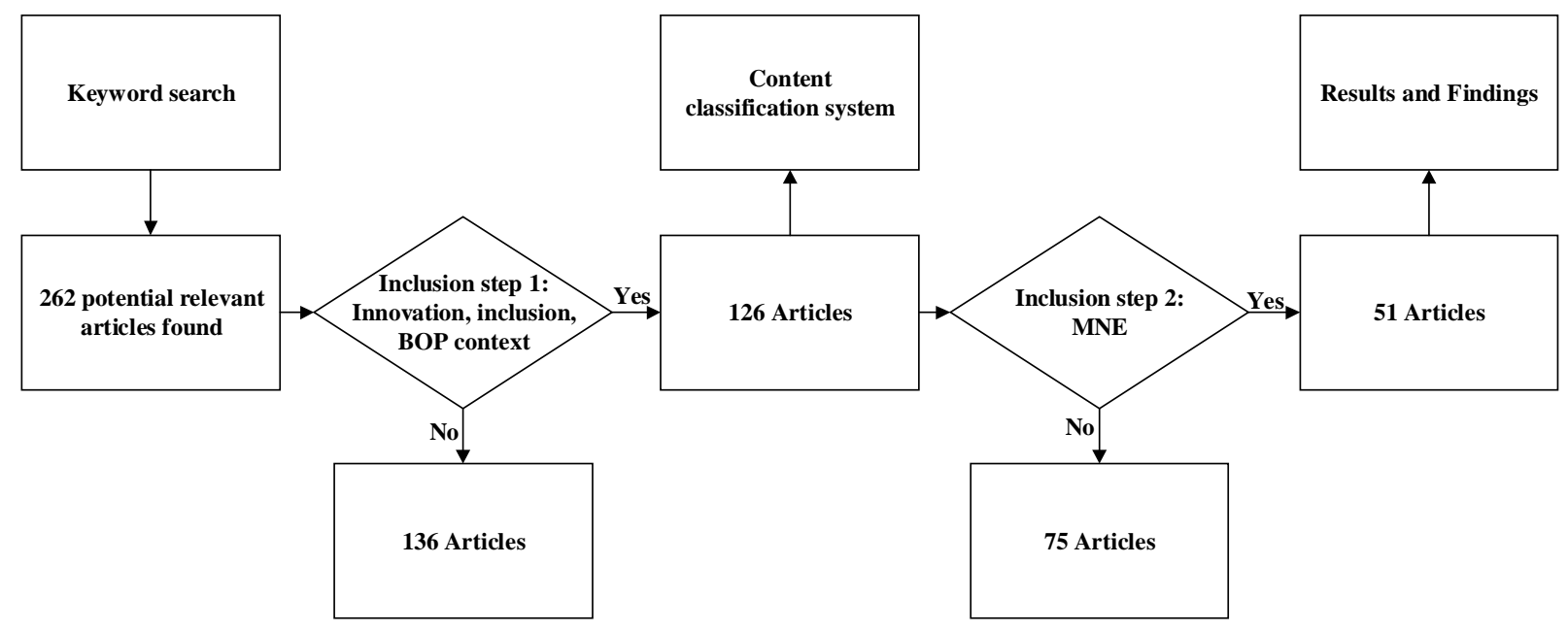

Figure 1. Research process for systematic review 


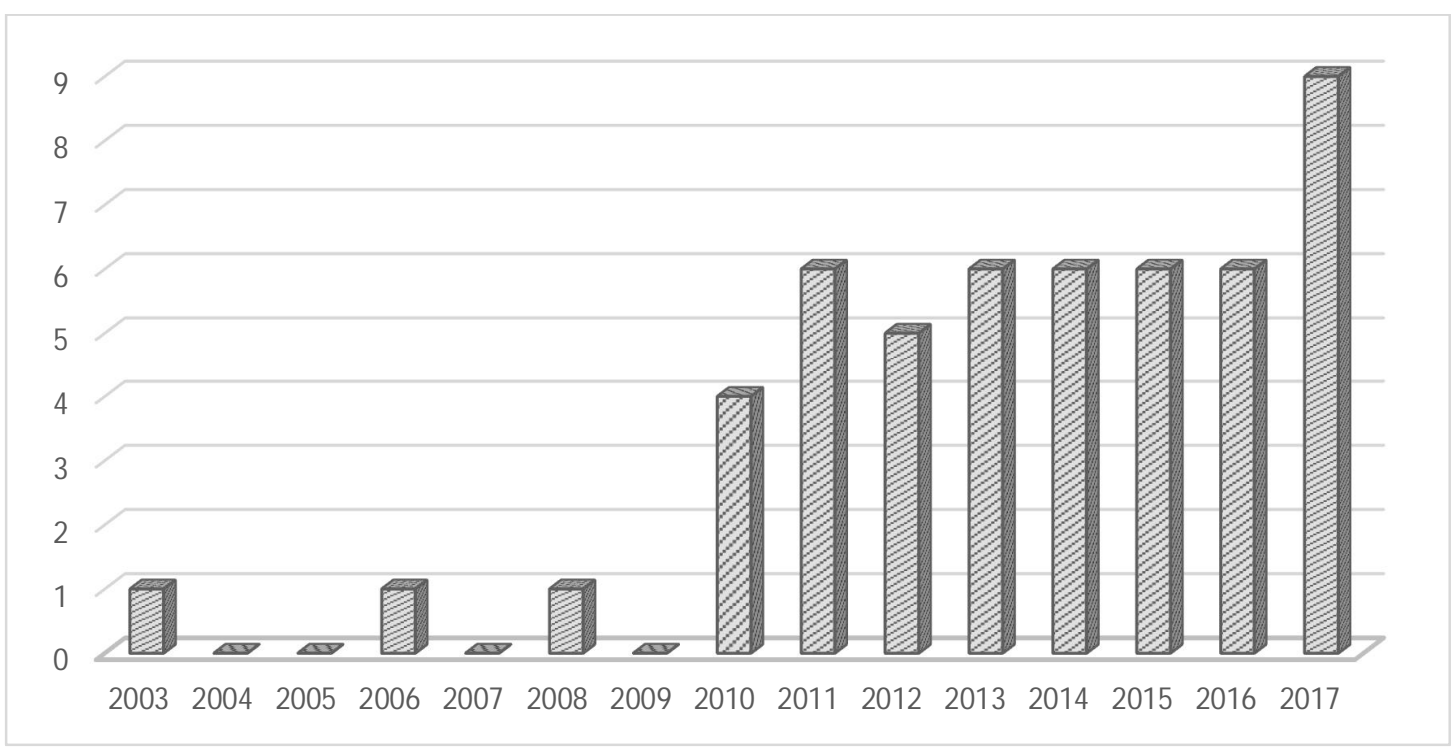

Figure 2. Number of articles per year 


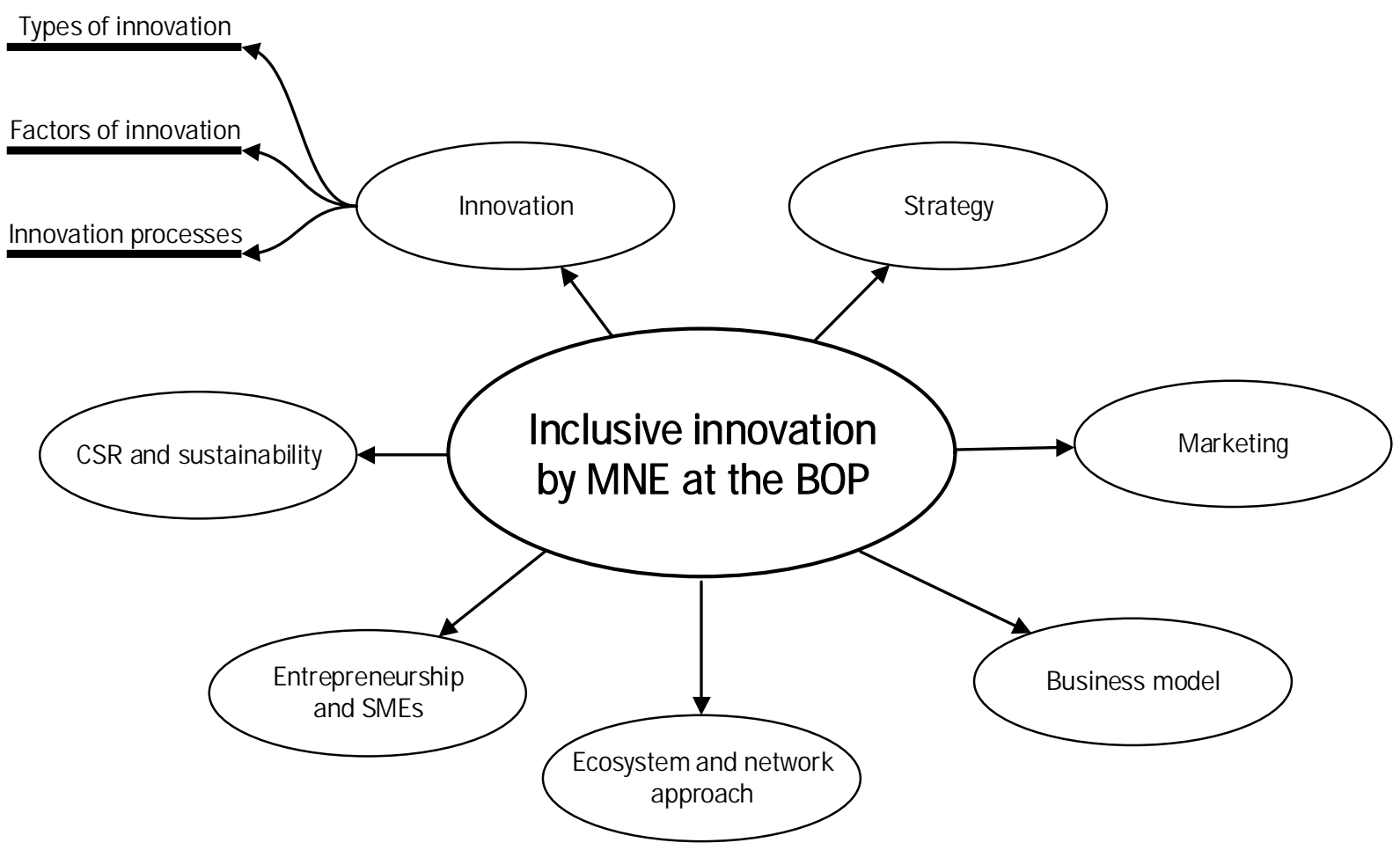

Figure 3. Inclusive Innovation at the BOP from the perspective of MNE 
Table 1. Classification of journals

\begin{tabular}{|c|c|c|c|c|c|}
\hline & Journal & $\begin{array}{l}\text { Count } \\
(\mathrm{N}=51)\end{array}$ & $\begin{array}{c}\text { Proportion } \\
(\%)\end{array}$ & ABS Field & $\begin{array}{l}\text { ABS } \\
\text { level }\end{array}$ \\
\hline 1 & Technological Forecasting and Social Change & 4 & 7,84 & Social science & 3 \\
\hline 2 & Technology in Society & 4 & 7,84 & - & - \\
\hline 3 & Technovation & 4 & 7,84 & Innovation & 3 \\
\hline 4 & Journal of Indian Business Research & 3 & 5,88 & - & - \\
\hline 5 & Journal of Business Strategy & 2 & 3,92 & - & - \\
\hline 6 & Journal of Service Management & 2 & 3,92 & Sector studies & 2 \\
\hline 7 & Organization and Environment & 2 & 3,92 & $\begin{array}{c}\text { Organizational } \\
\text { studies }\end{array}$ & 2 \\
\hline \multirow[t]{2}{*}{8} & Strategy and Leadership & 2 & 3,92 & - & - \\
\hline & Other journals & 28 & 54,9 & & \\
\hline
\end{tabular}


Table 2. Classification of articles

\begin{tabular}{|c|c|}
\hline & $\begin{array}{l}\text { Number of articles } \\
\qquad(\mathrm{N}=51)\end{array}$ \\
\hline \multicolumn{2}{|l|}{ Research methods } \\
\hline Case studies & 28 \\
\hline Conceptual & 11 \\
\hline Literature review & 5 \\
\hline Archival studies & 1 \\
\hline Survey & 0 \\
\hline Others & 6 \\
\hline \multicolumn{2}{|l|}{ Industry settings } \\
\hline Single industries: & 23 \\
\hline Service & 15 \\
\hline Consumer goods & 5 \\
\hline Transportation and logistics & 2 \\
\hline Food and beverage & 1 \\
\hline Public administration & 0 \\
\hline Multiple industries & 15 \\
\hline Not specified & 13 \\
\hline
\end{tabular}

\section{MNEs' headquarter location}

Single continent/region:

$\begin{array}{rr}\text { Europe } & 6 \\ \text { Asia } & 6 \\ \text { North America } & 4 \\ \text { Latin America } & 0 \\ \text { Africa } & 0 \\ \text { nd New Zealand } & 0\end{array}$

Multiple continents/regions 23

Not specified 12

\begin{tabular}{lr}
\hline \multicolumn{2}{l}{$\begin{array}{l}\text { Geographic context of the study } \\
\text { Single continent/region: }\end{array}$} \\
Asia & 24 \\
Africa & 19 \\
Latin America & 1 \\
Europe & 0 \\
North America & 0 \\
Australia and New Zealand & 0 \\
Multiple continents/regions & 14 \\
Not specified & 13 \\
\end{tabular}


Table 3. Description of the codes

\begin{tabular}{|c|c|}
\hline $\begin{array}{l}\text { Research } \\
\text { methodologies }\end{array}$ & $\begin{array}{l}\text { We classified articles into case studies, conceptual or } \\
\text { theoretical papers, survey studies, literature reviews, and } \\
\text { archival studies. Articles that specifically talked about } \\
\text { or focused on several types of research methods were } \\
\text { coded as others. All additional methodologies were } \\
\text { codes as others. }\end{array}$ \\
\hline \multirow[t]{6}{*}{$\begin{array}{l}\text { Industry } \\
\text { settings }\end{array}$} & $\begin{array}{l}\text { We coded all articles as single-industry studies, multiple } \\
\text { industry studies or industry not specified. The more } \\
\text { specific industry setting was additionally coded for } \\
\text { articles that were codes as single industry studies. The } \\
\text { five industry codes used are: }\end{array}$ \\
\hline & $\begin{array}{l}\text { Consumer goods: goods such as textiles, cellphones } \\
\text { and appliances, and medicines were coded in this } \\
\text { category. }\end{array}$ \\
\hline & $\begin{array}{l}\text { Food and beverage: foods and beverages included } \\
\text { various types of edible products and beverages. }\end{array}$ \\
\hline & $\begin{array}{l}\text { Transportation and logistics: transportation, logistics, } \\
\text { and other commuting matters. This code also covered } \\
\text { related industries such as road constructions. }\end{array}$ \\
\hline & $\begin{array}{l}\text { Public administration: governmental services and } \\
\text { public organizations. }\end{array}$ \\
\hline & $\begin{array}{l}\text { Services: various types of services in the private or } \\
\text { public sectors (e.g. healthcare, IT services, } \\
\text { telecommunications). }\end{array}$ \\
\hline $\begin{array}{l}\text { MNEs' } \\
\text { headquarter } \\
\text { location }\end{array}$ & $\begin{array}{l}\text { We coded all articles for the specific continent of the } \\
\text { headquarters of the MNE that the data was related to. } \\
\text { We only coded headquarter locations for articles with } \\
\text { single cases (a single MNE as a case company). }\end{array}$ \\
\hline $\begin{array}{l}\text { Geographic } \\
\text { context of the } \\
\text { study }\end{array}$ & $\begin{array}{l}\text { We coded all articles in this category as single continent } \\
\text { studies, multiple continent studies or Not specified. This } \\
\text { refers to the continent or the region that data was } \\
\text { collected in or that the data relates to. The specific } \\
\text { continents were only coded for articles with a single } \\
\text { geographic context. }\end{array}$ \\
\hline
\end{tabular}


Table 4.Types of innovation

\begin{tabular}{|c|c|c|}
\hline Types of innovation & Authors & Implications for MNEs \\
\hline Frugal innovation & $\begin{array}{l}\text { Tiwari \& Herstatt (2012) } \\
\text { Jha \& Krishnan (2013) } \\
\text { Nari Kahle et al., (2013) } \\
\text { Leavy (2014) } \\
\text { Ojha (2014) } \\
\text { Agnihotri (2015) } \\
\text { Pansera \& Owen (2015) } \\
\text { Altmann \& Engberg (2016) } \\
\text { Hossain et al., (2016) } \\
\text { Dellermann (2017) } \\
\text { Malik (2017) } \\
\text { Rao (2017) } \\
\text { Rosca et al (2017) }\end{array}$ & $\begin{array}{l}\text { MNEs can foster frugal innovation } \\
\text { through better product design, } \\
\text { knowledge-based strategies, affordable } \\
\text { resources through engineering and } \\
\text { robust relationship with customer and } \\
\text { supplier. }\end{array}$ \\
\hline Jugaad innovation & $\begin{array}{l}\text { Jha \& Krishnan (2013) } \\
\text { Agnihotri (2015) } \\
\text { Pansera \& Owen (2015) } \\
\text { Prabhu \& Jain (2015) }\end{array}$ & $\begin{array}{l}\text { Jugaad can be fostered through } \\
\text { eliminating resource constraints and co- } \\
\text { creation with customers. }\end{array}$ \\
\hline Reverse Innovation & $\begin{array}{l}\text { Jha \& Krishnan (2013) } \\
\text { Leavy (2014) } \\
\text { Agnihotri (2015) } \\
\text { Hossain et al., (2016) } \\
\text { Dellermann (2017) } \\
\text { Rosca et al (2017) }\end{array}$ & $\begin{array}{l}\text { Fostering reverse innovation by MNEs } \\
\text { creates more value for the society profit } \\
\text { for the company. }\end{array}$ \\
\hline Social innovation & $\begin{array}{l}\text { Reynoso et al., (2015) } \\
\text { Halme et al, (2016) }\end{array}$ & $\begin{array}{l}\text { Social innovation is rendered through } \\
\text { the creative upgrade of technology, } \\
\text { strong stakeholder coordination and } \\
\text { effective distribution channels. This can } \\
\text { result in more operational activities by } \\
\text { the MNEs and prosperity for the people. }\end{array}$ \\
\hline Product innovation & $\begin{array}{l}\text { Waeyenberg \& Hens (2008) } \\
\text { Ray \& Kanta Ray (2011) } \\
\text { Chakravarthy \& Coughlan } \\
\text { (2011) }\end{array}$ & $\begin{array}{l}\text { The design phase of Product } \\
\text { development must be achieved through } \\
\text { systems of actors in the market. This } \\
\text { can result in effective product } \\
\text { innovation for MNEs. }\end{array}$ \\
\hline $\begin{array}{l}\text { Business model } \\
\text { innovation }\end{array}$ & $\begin{array}{l}\text { Angeli \& Jaiswal (2016) } \\
\text { Gebauer et al., (2017) }\end{array}$ & $\begin{array}{l}\text { Business model innovation can be } \\
\text { implemented by, "co-creation, value } \\
\text { creation, community engagement, } \\
\text { continuous involvement of customers. }\end{array}$ \\
\hline
\end{tabular}


Table 4. Types of innovation (continued)

\begin{tabular}{|c|c|c|}
\hline Types of innovation & Authors & Implications for MNEs \\
\hline Open innovation & Dellermann (2017) & $\begin{array}{l}\text { Open network relations can enhance the } \\
\text { growth and competitiveness of MNEs } \\
\text { and generate innovation for BOP. }\end{array}$ \\
\hline Inclusive innovation & $\begin{array}{l}\text { Foster \& Heeks (2013) } \\
\text { Gebauer \& Reynoso (2013) }\end{array}$ & $\begin{array}{l}\text { Tools like service dominant logic, local } \\
\text { engagement and low-cost innovation } \\
\text { activities by MNEs can lead to inclusive } \\
\text { innovation. Inclusive innovation is } \\
\text { fostered when MNEs include } \\
\text { marginalized portions of the society into } \\
\text { their market. }\end{array}$ \\
\hline $\begin{array}{l}\text { Gandhian } \\
\text { innovation }\end{array}$ & Leavy (2014) & $\begin{array}{l}\text { Innovation constraints can be lifted by, } \\
\text { modifying organization capability, } \\
\text { disrupting business model and sourcing } \\
\text { new capabilities. }\end{array}$ \\
\hline $\begin{array}{l}\text { Disruptive } \\
\text { innovation }\end{array}$ & $\begin{array}{l}\text { Pervez et al., (2013) } \\
\text { Leavy (2014) } \\
\text { Reficco \& Gutiérrez (2016) }\end{array}$ & $\begin{array}{l}\text { Venturing with other organizations in } \\
\text { the BOP market can foster disruptive } \\
\text { innovation. }\end{array}$ \\
\hline Radical innovation & Pels \& Sheth (2017) & $\begin{array}{l}\text { Radical innovation is a good solution } \\
\text { for MNEs to operate BOP markets as it } \\
\text { allows these companies to render } \\
\text { innovation according to the } \\
\text { environmental changes of the market }\end{array}$ \\
\hline $\begin{array}{l}\text { Architectural } \\
\text { innovation }\end{array}$ & Ray \& Ray (2010) & $\begin{array}{l}\text { User demands can be handled through } \\
\text { architectural innovation, taking in to } \\
\text { account affordability, functionality, and } \\
\text { operability of the products }\end{array}$ \\
\hline Value innovation & Williams et al., (2011) & $\begin{array}{l}\text { Value innovation is a strong tool that } \\
\text { can help MNEs to foster innovation } \\
\text { through creating value for their } \\
\text { customers and themselves }\end{array}$ \\
\hline
\end{tabular}


